\title{
Government Social Media Existence: Case Study on the Use of Twitter Regional Disaster Management Agency, Province of Yogyakarta Special Region
}

\author{
Addin Khaerunnisa Juswil ${ }^{1}$, Sanny Nofrima ${ }^{2}$ \\ 1,2 Masters of Government Affairs and Public Administration, Universitas Muhammadiyah \\ Yogyakarta, Jl. Brawijaya, Kasihan, Bantul, Yogyakarta, Indonesia 55183
}

Corresponding author: sannynofrima21@gmail.com

\begin{abstract}
The proper utilization of social media is crucial in terms of disaster management, especially by the government. One of the government's method to accelerate the dissemination of information regarding disasters is through official government's Twitter account which has proven to be more effective. This study aims to describe the efforts of the Regional Disaster Management Agency (BPBD) of the Special Region of Yogyakarta in handling crisis through a managed twitter account, namely @pusdalops_DIY. This research uses descriptive qualitative research method which is carried out by analyzing the Twitter using NVivo 12 Plus data processing software. The result of this study can be stated that the utilization of the Regional Disaster Management Agency (BPBD) Twitter account of the Special Region of Yogyakarta has been effective in disseminating informations and compatible with the main tasks also functions listed in the regional legal basis regarding the Regional Disaster Management Agency (BPBD). However, it still requires further digitalization in all areas of government to be more integrated and communicative in crisis management.
\end{abstract}

Article Info :

\section{INTRODUCTION}

The current world dialectics cannot be separated from the technological influence due to its massive technological developments. The industrial revolution bring changes in many life aspects, one of them is social media creation as the most discussed studies today. On daily basis, the use of social media can no longer be avoided, it definitely has dynamic trend, for example, in 2009 and 2015, social media was arguably a very small influence specifically on the world's political conditions. It turns out drastically in 2016, social media showed significant impact on world political constellations as it is thought to affect many aspects in politics and governance (Dimitrova \& Matthes, 2018). The use of social media in matters related to the state proved to be initiated from the beginning of the campaign process to the process of

Please cite this article as: Juswil, A., \& Nofrima, S. (2020). Government Social Media Existence: Case Study on the Use of Twitter Regional Disaster Management Agency, Province of Yogyakarta Special Region).Journal of Local Government Issues (Logos), 3(2), 98-110. 
subsequent policy formulation (Stier et al, 2018). The use of digital space can be able to connect communication in a geographic barrier with the utilization of the organization in order to support the communication process, and the use of digital technology to conduct deliberations and coordination in information that is the political attitude of the organization (Kurniawan \& Yulistyo, 2018).

In the Indonesian context, the most prominent from the first leadership period of President Joko Widodo is the use of social media that massively conducted by the President as Head of State as well as head of government. In his personal Twitter account, President Joko Widodo frequently preached matters related to foreign policy, social and defense and security (Ichsani, Amir, \& Yusuf, 2019). The use of social media is not only done by the president but also spread out by other organizations in the ranks of government, both from individual as well as institutional accounts, on the national level and regional levels, the level 1 (provincial) and District Level 2 (district/city), even the level of the village.

Social media in the Indonesian regional context does demonstrate a good impact on establishing active communication between regions, both at the government level and the inter-community level (Moriansyah, 2016). As the country with archipelago geographical form, this will facilitate and accelerate the occurrence of information exchange. Some studies on social media also show a good impact on government, in the public finance sector, for example, social media can indicate the implementation of good governance (Rini \& Sagoro, 2016) and demonstrate the government's commitment to the creation of transparency (Porumbescu, 2016). Other example, social media plays an important role in improving the performance of its main government maximum efforts to response on the aspirations of communities in the region (Rahayu, Setyarto, \& Efendi, 2015), the high level of government's responsiveness then improving the community's trust to re-use social media in reporting on the things happening in the community itself (Tromble, 2018), given how the community participation in social media was influenced by friendship-driven or interest-driven (Kahne \& Bowyer, 2018).

The more effectiveness of government performance through social media intermediaries is something that Ridwan Kamil tried to run in the government until finally managed to create social media as one of the community mobilizers (creating a social movement) (Mayangsari \& Ryan, 2016), this condition tries to emulate the success that the Non-Governmental Organization (NGO) has achieved in the massbreaking process and advocacy by social media (Gupta, Ripberger, \& Wehde, 2018). In the social media context, Ridwan Kamil has not only created social movements among his followers, but the communication pattern Ridwan Kamil has done through social media is also considered proven to cut the bureaucracy procedures in Bandung when he serving the community (Munandar \& Suherman, 2016), even improve the satisfaction of the community to the government response to reach the number $73.82 \%$ (Khairunnisa \& Anggadwita, 2018). Another form of how the implementation of social media usage affects the level of trust in Seoul, South Korea (Eom, Hwang, \& Kim, 2018), even a communist country implementing a one-way policy system is trying to incorporate social media into the process of absorption of community aspirations and the process of running e-government practices, although his tendency to continue to use social media

99 | Journal of Local Government Issues (Logos), 3 (2), September 2020, pp. 98-110 ISSN : 2620-8091 print | 2620-3812 online 
as the suggestion to silence existing criticism of the government and prevent the dissemination of information that is not relevant with the government rules (King, Pan, \& Roberts, 2017).

In social media, the most widely used by politicians and governments in the communication intent is Twitter and Facebook, although these social media have a difference in terms and effectiveness of its use in conveying message messages, both remain the most frequently used by government actor political actors (Gao \& Lee, 2017). Equivalently, according to Schwanhollz, Graham, and Stoll, social media is often used to perform a government setting agenda, one of those figure that often uses this approach is the controversial politician Geert Wilder (Schwanholz, Graham, \& Stoll, 2018). According to the Twitter founder, Dic Costolo, Twitter users in Indonesia play an important role considering Indonesia is one of the countries with a large population that makes Twitter as part of their daily activities (Susanto, 2017). Even according to statistical data in the process of the Indonesian elections, there are 95 million Twitter accounts performed either through a single tweet or in the form of Kultwit (Firmansyah et al, 2018). The number of use showing the enthusiasm of Indonesian in using social media primarily Twitter, although the fact that the use of social media in Indonesia has not been sufficiently protected by the law due to the existence of Electronic Transactions and Information Law (ITE) which often causes the limited criticism that can be conveyed through social media (Pratiwi, Bungin, \& Soenarjanto, 2015).

There are some studies that have tried to approach the specific use of social media by actors who are involved in the public sector, not only executives but also in the parliamentary/legislative context (Daniel, Obholzer, \& Hurka, 2019). Although the study in the context of executives is more demanding as executor of policy, the executive figure is certainly more visible than the public, as the previous statement, in addition to the focus of social media study is individual figure. Especially when the world level event is being held and involving state leaders such as in the The North Atlantic Treaty Organization (NATO) Summit Conference by the US President, French President, German Chancellor and Prime Minister of Canada (Walton, 2019).

Indonesia as a large country and located in the area called Ring of Fire is a country that is susceptible to potential disasters, according to the data from the National Disaster Management Agency, in the year of 2019 from January to March, Indonesia has experienced 1,132 natural disasters, with the number of victims impacted to 649,659 people. The most catastrophic occurs in the island that became the central development of Indonesia, Java Island, with the first place occupied by Central Java with a total of 429 disasters, then followed by West Java with the number up to 269, and East Java with 216 natural disasters. The amount of disaster experienced by Indonesia should be coupled up with the improvement of public insight on the matters related to the disaster itself, considering some study shows that the public knowledge and dissemination of information related to disasters is still very low due to the inequality of public information (Zulfa \& Firmansyah, 2019). In addition, the coverage of the news media that only focus on the post-disaster security conditions and other events that are still exist in the post-disaster of 2018. One form of efforts to improve public insight on the matter of disaster can be done through the proper use of social media by institutions

100 | Journal of Local Government Issues (Logos), 3 (2), September 2020, pp. 98-110 ISSN : 2620-8091 print | 2620-3812 online 
related to the disaster itself, usually the usage of this information will be more massive in the discussion regarding the fire point on a forest fire or news about the potential occurrence of earthquakes (Athanasis et al, 2018).

Currently, the National Disaster Management Agency (BNPB) as the main institution with disaster management task has the main social media Twitter in order to support the disaster education process. Currently focus on the use of social media Twitter owned by (BNPB) is in the provision of information in every aspect of management disaster (Fahriyani, Harmaningsih, \& Yunarti, 2020). In general, the system of governance of disaster management information conducted by this institution is by the method of system development cycle in the form of a waterfall which means the model is a groove from above (Djangoan, 2019).

Yogyakarta Special Region as an area that is frequently hit by natural disasters has made several efforts in terms of improving this disaster literacy. The first effort od proper utilization of social media has been attempted by several institutions, such as in the School of Mount Merapi which has incorporated social media as part of the socialization process of disaster mitigation, it is also done as an effort to soothe citizens from the anxiety of circulating its hoaxes regarding Merapi eruption (Minanto \& Ningsih, 2018), given that there is a tendency for society to spread massive information related to the disasters that have just experienced and communicate both with people in the region and not (Kim \& Hastak, 2018). Social media usage during disaster mitigation also can strengthen citizen participation, it can be work as an early warning in the disaster mitigation phase (Mauroner \& Heudorfer, 2016).

Apart from outside parties, the central institutions in the area of disaster management, the Regional Disaster Management Agency (BPBD), both of the district city and provincial level in the Special Region of Yogyakarta have also tried to use Twitter in the process of spreading disaster information. At the provincial level, this realization has attempted to be built by (BPBD) Yogyakarta through their official Twitter account, @Pusdalops_DIY. Regional management Agency BPBD Yogyakarta Special Region is an institution that is authorized by the Governor Regulation Number 8 the Year 2018, as the central institution that performs coordination and action when the use of social media conducted by a disaster management agency running effectively, should community participation in the process of spreading news related to the disaster will be increased by itself through the method of remote sensing or social sensing ( $\mathrm{Li}$, Huang, \& Emrich, 2019).

There are some criticisms related to the study of social media use in disaster management systems, including the far-flung study conducted as it usually covers all social media used by agency (Wang \& Ye, 2018). In Indonesia, the study in social media usage by disaster management agency only focused on social media usage by BNPB not regionally (BPBD). Therefore, the study will focus on the effectiveness of social media usage primarily by Twitter by the Regional Disaster Management Agency (@pusdalops_DIY) in socializing matters related to disasters.

In Indonesia, some studies have analyzed the functions of social media for the government in several ways. Firstly, in Central Java, through the study of Purwadi, Pratama, \& Mahendradi (2019), it can be seen that the social media accounts

101 | Journal of Local Government Issues (Logos), 3 (2), September 2020, pp. 98-110 ISSN : 2620-8091 print | 2620-3812 online 
(Facebook) of each local government totaling 32 can be an instrument to measure the level of community attachment to the government. Through followers, posts, likes, comments, and shares, it can be determined how much public interests and participating in government administration/public affairs. Secondly, social media (Whatsapp, Instagram, Youtube, and Facebook) are quite effectively used as a means of disseminating activity programs carried out by the Regional Secretariat of Pangandaran Regency (Novianti et al, 2020). This also took place in the Aceh Government which also contributed greatly to the formation of a positive image of the government in the eyes of the community (Juanda, 2017). Such a positive image is largely determined by the quality of the information or the post made.

Reflecting on the experience of the Medan City Government, the information conveyed through the Instagram page are news of work reports, information, and appeals, felicitations, videos, good figures have a strong correlation with the positive image given by the community (Effendi, Hendra, \& Matondang, 2019). Thirdly, social media becomes a channel for the interaction process between government and society (public communication). The study conducted by Anggreani, Purnomo, \& Kasiwi (2020) concludes that the twitter account used by the Yogyakarta City Government is very responsive in responding to the aspirations and complaints of the public regarding public services. Meanwhile, the Surabaya City Government Twitter account is more focused on delivering information to residents of Surabaya, especially regarding city government innovations.

Finally, the study by Salahudin et al, (2020) sees that the coordination strength of the Indonesian government in handling Covid-19 can be tracked via Twitter. By photographing the Twitter account of Jokowi (President of Indonesia), the Covid-19 Task Force for the Governor of Central Java, the Governor of West Java, the Governor of DKI Jakarta, the Governor of South Sulawesi, the Governor of West Nusa Tenggara, and the Governor of East Java, it can be seen that all relevant stakeholders have the same vision to solve. Covid-19, however, has several different approaches according to the context of the problems at hand so that the coordination model is also different. This study is slightly different because it is seen only in the delivery of key information related to the crisis conducted by the Yogyakarta Regional Disaster Management Agency (BPBD).

\section{METHOD}

This study uses qualitative study methods. Qualitative method is defined as a method that conclude the data and media that exist in writing or contextual. The qualitative method used in this study is a descriptive qualitative method using the help of NVivo 12 Plus data application. Broadly, this study refers to the following thread below (see Figure 1).

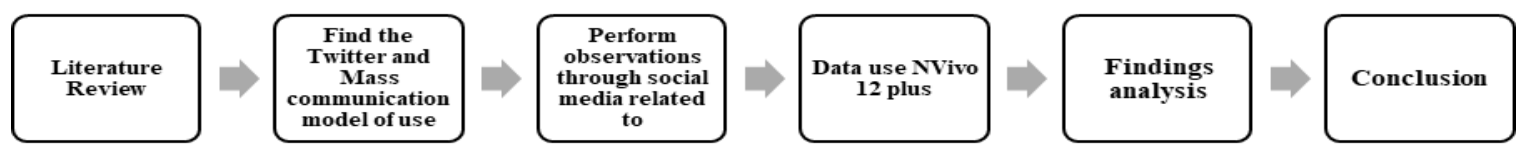

Figure 1. Method of a Article

102 | Journal of Local Government Issues (Logos), 3 (2), September 2020, pp. 98-110 ISSN : 2620-8091 print | 2620-3812 online 
The data of this study based on the literature review to find issues related to study and theories and data supporting this study. The data was made as a theoretical framework that serves as a guide in conducting data retrieval and analysis. Moreover, after the authors took data retrieval using NCapture and processed directly with the help of data processing software NVivo 12 plus. NVivo 12 Plus is a software that used as a place to automatically processing the data, so that the study can be done without any restriction of place and time, especially in study related to big data. The results then become analytical materials and adjusted to the existing frame of thought as a result of the literature review conducted at the beginning. Next, after the analysis process is completed, the results have concluded the study. In this study, the authors conduct the study using the journal and books and literature that is relevant as a source of literature studies, then the social media data is obtained by processing the social media data on Twitter-owned by BPBD DIY, which is @pusdalops_DIY account using NVivo 12 Plus.

\section{RESULTS AND DISCUSSION}

Website 2.0 as two-way create and exchange content among users in social media that affects how to communicate in the community with the presence of all information to be quickly accessible, but social media can also provide opinions and perceptions of different people. Social media can help people interact with the government easily and can use technology that transforms communication into interactive dialogue. The use of Twitter in Indonesia is arguably massive. It shows significant numbers, even the Chief Executive Officer (CEO) of Twitter himself stated that Indonesia does have a central role in Twitter's business journey (Susanto, 2017).

The role of social media in government becomes a tool that can accommodate the dissemination of information to the community and can accommodate the management of community aspirations in building community confidence to maintain the government's reputation so that creative effort is needed to use social media in government agencies.

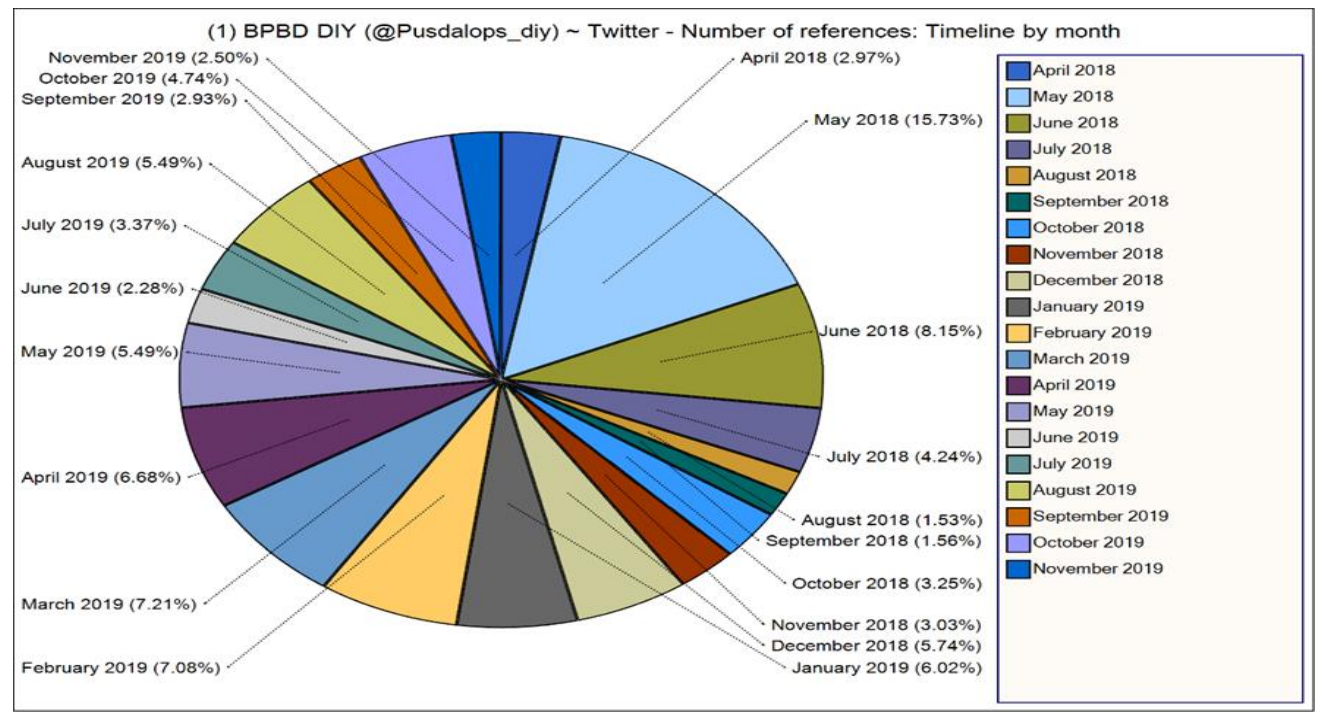

Figure 2. The intensity of Twitter Activity

103 | Journal of Local Government Issues (Logos), 3 (2), September 2020, pp. 98-110 ISSN : 2620-8091 print | 2620-3812 online 
Twitter is one of the social media that elicits mass communication in the dissemination of information and the intensity of Twitter activity. The above data (see Figure 2) is taken through NVivo 12 Plus which displays the existence of Twitter Regional Disaster Management Agency (BPBD) Yogyakarta from 2018 until 2019. Based on the data index in May 2018 District Disaster Management Agency (BPBD), Yogyakarta has a percentage of $15.73 \%$ this month there has been a phreatic eruption of Mount Merapi, via Twitter, regional disaster Management Agency (BPBD) Yogyakarta urged the people to avoid the radius of 3 kilometers from the summit. BPDP DIY via Twitter appealed to community to be aware of the phreatic eruption of Mount Merapi. Whereas in June of 2018, had a percentage of 8.15\%, in this month, the District Disaster Management Agency (BPBD) Yogyakarta explained that there had been an eruption of Merapi volcano, as well as asking the community to be prepared in the disaster-ready. The use of Twitter in standby or disaster emergency response operations does have an important role in mobilizing the masses and minimalizing the number of victims that will be inflicted, due to the rapid information that comes to the other party using the social media.

This also contributes to the efforts of minimize citizen's anxiety due to hoaxes in circulation, considering the tendency to disseminate post-disaster information (Kim \& Hastak, 2018). The intensity of Twitter usage of regional Disaster Management Agency (BPBD) Yogyakarta Special Region (DIY), from the above picture, can also be assessed how effective of management Twitter by BPBD DIY is. There are two types of management processes, the first type is the management under the individual, the second type is the collective management process by using one or more administrators (Ibrahim, Pratama, \& Rendy, 2018). BPBD DIY as an institution shows the second method, and from the number of tweets presentation, every month can be concluded that the use of administrator in the Twitter governance of regional Disaster Management Agency (BPBD) Special Region of Yogyakarta has been running effectively.

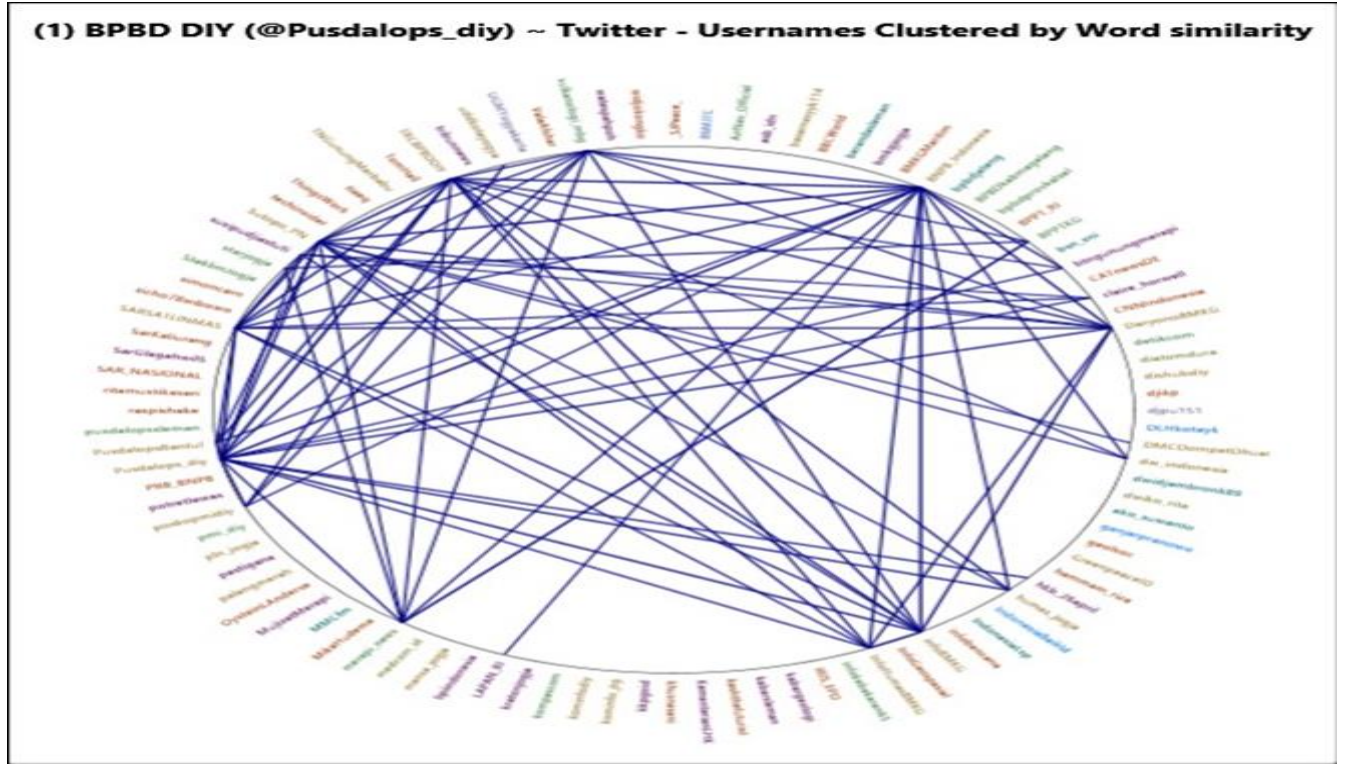

Figure 3. Word Similarity NVivo 12 Plus

104 | Journal of Local Government Issues (Logos), 3 (2), September 2020, pp. 98-110 ISSN : 2620-8091 print | 2620-3812 online 
Based on the analysis of Word similarity NVivo12 Plus (see Figure 3), @Pusdalops_DIY is more effective in spreading information by social media. In addition, based on the picture above, it can be seen that most interactions conducted by the Regional Disaster Management Agency (BPBD) Yogyakarta Special Region through @pusdalops_DIY account are indeed focused on matters related to disasters. The interaction conducted by the Regional Disaster Management Agency (BPBD) Special Region of Yogyakarta is more visible in other government institutions that still relate to the presence of disasters, such as the account of Search and Rescue (SAR) or Meteorological Agency Climatology and Geophysics (BMKG). Moreover, there are also other interactions with some non-governmental institutions that are also engaged in disasters such as Muhammadiyah Disaster Management Center (MDMC) or the Fast Response Action (ACT). Communication interactions are still more likely to be seen in one direction and not participate with the community considering the number of replies made to the community relatively small.

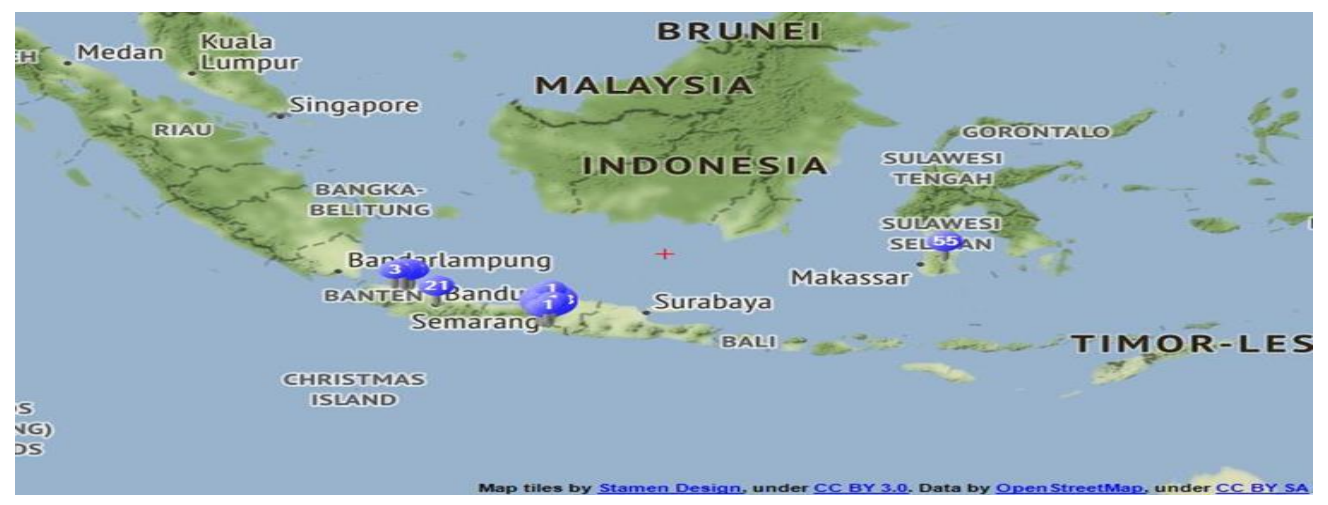

Figure 4. Map NVivo12 Plus

Based on the exposure data spread in Twitter, it can be seen that the use of Twitter regional Disaster Management Agency (BPBD) Special Region of Yogyakarta currently more focused on the coverage of things related to the disaster in Yogyakarta. The use of regional Disaster Management Agency (BPBD) Yogyakarta Special Region is already included quite extensive because it has several times spreading the disaster information in other areas, it can be seen from the number of tweets that reached 55 times from South Sulawesi (see Figure 4). The province of South Sulawesi in January 2019 , is a province that frequently hit by disasters, mainly is a flood and landslides with 69 people died as victims. In the analysis above can also be seen that the regional Disaster Management Agency (BPBD) Special Region of Yogyakarta has enough cooperation with international disaster actors, considering the existence of several tweets from foreign countries.

In describing the utilization of social media in the government, some key factors support the effectiveness of social media use in the government, including 1) leadership commitments; 2) clear legal umbrella; 3) policy framework; and 4) management of policies. In the implementation of social media use by the Regional Disaster Management Agency (BPBD) Special Region of Yogyakarta, the most obvious supportive factor is the existence of a legal umbrella for the use of this social media. Governor of

105 | Journal of Local Government Issues (Logos), 3 (2), September 2020, pp. 98-110 ISSN : 2620-8091 print | 2620-3812 online 
Yogyakarta Regulation Article 5 No 80 the Year 2018 listed one of the tasks of regional disaster Management (BPBD) Yogyakarta Special Region is "Drafting, the determination, informing the map of disaster risk and permanent procedure of disaster management". It can be seen that one of the main things to do by regional disaster Management (BPBD) Special Region of Yogyakarta is to be the main source of information related to disasters, so this can be the official regulation for the use of social media conducted by regional disaster Management (BPBD) Special Region of Yogyakarta. Based on the law protection, the provincial government has demonstrated its commitment in the effort to digitize the dissemination of disaster information conducted by regional Disaster Management (BPBD) Special Region of Yogyakarta. This legal umbrella also works as the policy framework in implementing social media usage in disaster information dissemination.

It can be concluded that the selection of Twitter as an information dissemination tool is appropriate. Considering according to the study, Twitter is the most influential social media in the speed of dissemination of information. This is different from Facebook that tends to be done in terms of time frame (Oz, Zheng, \& Chen, 2018), so that disaster information must be delivered rapidly in the main phase of preparation and emergency response has been pursued well by BPBD DIY.

\section{CONCLUSION}

This study proves that there is a positive adaptation conducted by government agencies (BPBD Yogyakarta) by integrating information technology into public services. It indicates the seriousness of the government as a public institution to improve the quality of public services to be more efficient and effective, which is also part of bureaucratic reform. Moreover, in a disaster situation, people need information quickly so that they can be responsive and adapt to the situation.

Disaster is a sector that requires a quick response from the government or other actors working in the field, one of the efforts to increase responsiveness is through the use of Twitter social media. In terms of the use of Twitter by the Regional Disaster Management Agency (BPBD) of the Special Region of Yogyakarta, although communication is still one-way, the Regional Disaster Management Agency (BPBD) of the Special Region of Yogyakarta via Twitter account @Pusdalops_DIY has succeeded in creating an effective channel of information on the subject of 201880.

In the future, to be more optimal, crisis communication through government social media accounts must be more interactive. There is a public space provided so that the communication between the community and the government can take place so that crisis management can be more focused. Therefore, supporting infrastructures such as information technology networks and the readiness of Human Resources (HR) need to be improved. Furthermore, it is time for the digitalization of public services can be applied in all government organizations to improve public satisfaction.

\section{REFERENCES}

Anggreani, M. D., Purnomo, E. P., \& Kasiwi, A. N. (2020). Ruang Publik Virtual Sebagai Pintu Komunikasi Government to Citizen (Studi Kasus: Perbandingan Media

106 | Journal of Local Government Issues (Logos), 3 (2), September 2020, pp. 98-110 ISSN : 2620-8091 print | 2620-3812 online 
Sosial Pemerintah Kota Yogyakarta dan Surabaya). Moderat: Jurnal Ilmiah Ilmu Pemerintahan, 6(1), 203-220. http://dx.doi.org/10.25157/moderat.v6i1.3165

Athanasis, N., Themistocleous, M., Kalabokidis, K., Papakonstantinou, A., Soulakellis, N., \& Palaiologou, P. (2018). The Emergence of Social Media for Natural Disasters Management: A Big Data Perspective. Int. Arch. Photogramm. Remote Sens. Spatial Inf. Sci, 42(3), W4. https://doi.org/10.1177/1354068817747755

Daniel, W. T., Obholzer, L., \& Hurka, S. (2019). Static and Dynamic Incentives for Twitter Usage in the European Parliament. Party Politics, 25(6), 771-781. https://doi.org/10.1177/1354068817747755

Dimitrova, D. V., \& Matthes, J. (2018). Social Media in Political Campaigning Around the World: Theoretical and Methodological Challenges. Journalism \& Mass Communication Quarterly, 95(2) 333-342. https://doi.org/10.1177/1077699018770437

Djangoan, T. (2019). Sistem Informasi Pengolahan Data Kegiatan Kebencanaan pada Kantor Badan Penanggulangan Bencana Daerah Provinsi Gorontalo. Skripsi: Universitas Negeri Gorontalo

Effendi, M. W., Hendra, Y., \& Matondang, A. (2019). Persepsi Masyarakat Tentang Citra Pemerintah Kota Medan Melalui Akun Media Sosial Instagram@ humas_pemkomedan. Perspektif, $\quad 8(1), \quad 20-26$. https://doi.org/10.31289/perspektif.v8i1.2541

Eom, S.-J., Hwang, H., \& Kim, J. H. (2018). Can Social Media Increase Government Responsiveness? A Case Study of Seoul, Korea. Government Information Quarterly, 35(1), 109-122. https://doi.org/10.1016/j.giq.2017.10.002

Fahriyani, S., Harmaningsih, D., \& Yunarti, S. (2020). Penggunaan Media Sosial Twitter untuk Mitigasi Bencana di Indonesia. IKRA-ITH Humaniora: Jurnal Sosial dan Humaniora, 4(2), 56-65.

Firmansyah, M. A., Mulyana, D., Karlinah, S., \& Sumartias, S. (2018). Kontestasi Pesan Politik dalam Kampanye Pilpres 2014 di Twitter: dari Kultwit hingga Twitwar. Jurnal Ilmu Komunikasi, 16(1), 42-53.

Gao, X., \& Lee, J. (2017). E-Government Services and Social Media Adoption: Experience of Small Local Governments in Nebraska State. Government Information Quarterly, 34(4), 627-634. https://doi.org/10.1016/j.giq.2017.09.005

Gupta, K., Ripberger, J., \& Wehde, W. (2018). Advocacy Group Messaging on Social Media: Using the Narrative Policy Framework to Study Twitter Messages About Nuclear Energy Policy in the United States. Policy Studies Journal, 46(1), 119-136. https://doi.org/10.1111/psj.12176

Ibrahim, M., Pratama, S., \& Rendy, M. (2018). Social Media Positioning Trend Analysis in 2017 Bangka Belitung Governor Election Campaign. Proceedings of the 5th International Conference on Social and Political Sciences (IcoSaPS 2018),241, 5560. https://dx.doi.org/10.2991/icosaps-18.2018.16

Ichsani, N., Amir, A. S., \& Yusuf, A. J. (2019). Twitter Presiden dan Representasi Kebijakan Pemerintahan Indonesia-Analisis Isi Twitter Presiden Jokowi. 
Juswil \& Nofrima

KAREBA: Jurnal Ilmu Komunikasi, 7(1), 54-64. https://doi.org/10.31947/kareba.v7i1.5479

Juanda, H. (2017). Media Sosial Sebagai Penyebarluasan Informasi Pemerintah Aceh.

Jurnal Peurawi: Media Kajian Komunikasi Islam, 1(1). http://dx.doi.org/10.22373/jp.v1i1.1988

Kahne, J., \& Bowyer, B. (2018). The Political Significance of Social Media Activity and Social Networks. Political Communication, 35(3), 470-493. https://doi.org/10.1080/10584609.2018.1426662

Khairunnisa, K., \& Anggadwita, G. (2018). Analisis Pengaruh Efektifitas Media Sosial Twitter Terhadap Government Open Communication Dengan Pendekatan Technology Acceptance Model (tam) pada Masyarakat Bandung. eProceedings of Management, 5(2).

Kim, J., \& Hastak, M. (2018). Social Network Analysis: Characteristics of Online Social Networks After A Disaster. International Journal of Information Management, 38(1), 86-96. https://doi.org/10.1016/j.ijinfomgt.2017.08.003

King, G., Pan, J., \& Roberts, M. E. (2017). How the Chinese Government Fabricates Social Media Posts for Strategic Distraction, Not Engaged Argument. American Political Science Review, 111(3), 484-501. https://doi.org/10.1017/S0003055417000144

Kurniawan, R., \& Yulistyo, D. (2018). Analisis Penggunaan Cerita Rakyat Bengkulu Dalam Pembelajaran Retorika/Komunikasi Massa. ESTETIK: Jurnal Bahasa Indonesia, 1(1), 85-100. http://dx.doi.org/10.29240/estetik.v1i1.513

Li, Z., Huang, Q., \& Emrich, C. T. (2019). Introduction to Social Sensing and Big Data Computing for Disaster Management: International Journal of Digital Earth, 12 (11), 1198-1204. https://doi.org/10.1080/17538947.2019.1670951

Mauroner, O., \& Heudorfer, A. (2016). Social Media in Disaster Management: How Social Media Impact the Work of Volunteer Groups and Aid Organisations in Disaster Preparation and Response. International Journal of Emergency Management, 12(2), 196-217. https://doi.org/10.1504/IJEM.2016.076625

Mayangsari, I. D., \& Ryan, H. (2016). Gerakan Sosial Folower Twitter@ Ridwan Kamil. Jurnal Ilmiah Liski (Lingkar Studi Komunikasi), 2(1), 116-123.

Minanto, A., \& Ningsih, I. N. D. K. (2018). Literasi Bencana di Sekolah Gunung Merapi Tentang Mitigasi Bencana dan Kewarganegaraan Transformatif. Wacana: Jurnal Ilmiah Ilmu Komunikasi, 17(2), 207-216.

Moriansyah, L. (2016). Motivasi, Sikap, dan Intensi Pengguna Media Sosial pada Kampanye Stop Illegal Fishing. Jurnal Manajemen \& Agribisnis, 13(3), 192-205. https://doi.org/10.17358/jma.13.3.192

Munandar, H., \& Suherman, M. (2016). Aktivitas Komunikasi Pemerintahan Ridwan Kamil di Media Sosial. Prosiding Hubungan Masyarakat, 2 (1), 423-429.

Novianti, E., Nugraha, A. R., Komalasari, L., Komariah, K., \& Rejeki, D. S. (2020). Pemanfaatan Media Sosial dalam Penyebaran Informasi Program Pemerintah (Studi Kasus Sekretariat Daerah Kabupaten Pangandaran). AL MUNIR: Jurnal

108 | Journal of Local Government Issues (Logos), 3 (2), September 2020, pp. 98-110 ISSN : 2620-8091 print | 2620-3812 online 
Komunikasi dan Penyiaran Islam, 1(1), 48-59. https://doi.org/10.15548/amjkpi.v0i0.1499

Oz, M., Zheng, P., \& Chen, G. M. (2018). Twitter Versus Facebook: Comparing Incivility, Impoliteness, and Deliberative Attributes. New Media \& Society, 20(9), 34003419. https://doi.org/10.1177\%2F1461444817749516

Porumbescu, G. A. (2016). Comparing the Effects of E-Government and Social Media Use on Trust in Government: Evidence From Seoul, South Korea. Public Management Review, 18(9), 1308-1334. https://doi.org/10.1080/14719037.2015.1100751

Pratiwi, T. A., Bungin, B., \& Soenarjanto, B. (2015). Kebebasan Berpendapat Melalui Facebook dan Twitter: Studi Kasus Undang-Undang Informasi dan Transaksi Elektronik. representamen, 1(1).

Purwadi, A., Pratama, A. B., \& Mahendradi, R. M. (2019). Mengukur Engagement Warga Negara dalam Interaksi Media Sosial (Studi pada 32 Akun Resmi Facebook Pemerintah Kabupaten/Kota di Jawa Tengah). Jurnal Natapraja: Kajian Ilmu Administrasi Negara, 7(1), 1-17. https://doi.org/10.21831/jnp.v7i1.24895

Rahayu, N. T., Setyarto, S., \& Efendi, A. (2015). Model Pewarisan Nilai-Nilai Budaya Jawa Melalui Pemanfaatan Upacara Ritual. Jurnal Ilmu Komunikasi, 12(1), 55-69.

Rini, S., \& Sagoro, E. M. (2016). Pengaruh Good Governance dan Pemanfaatan Teknologi Informasi Terhadap Kinerja Pegawai Keuangan Dinas Pemerintah Kabupaten Gunungkidul. Jurnal Profita: Kajian Ilmu Akuntansi, 4(2), 1-14.

Salahudin, A. N., Sulistyaningsih, T., Lutfi, M., \& Sihidi, I. T. (2020). Analysis of Government Official Twitters During Covid-19 Crisis in Indonesia. Journal of Talent Development and Excellence, 12(1), 3899-3915.

Schwanholz, J., Graham, T., \& Stoll, P.-T. (2018). Managing Democracy in the Digital Age. Springer.

Stier, S., Bleier, A., Lietz, H., \& Strohmaier, M. (2018). Election Campaigning on Social Media: Politicians, Audiences, and the Mediation of Political Communication on Facebook and Twitter. Political Communication, 35(1), 50-74. https://doi.org/10.1080/10584609.2017.1334728

Susanto, E. H. (2017). Media Sosial Sebagai Pendukung Jaringan Komunikasi Politik. Jurnal Aspikom, 3(3), 379-398.

Tromble, R. (2018). Thanks For (Actually) Responding! How Citizen Demand Shapes Politicians' Interactive Practices on Twitter. New Media \& Society, 20(2), 676697. https://doi.org/10.1177\%2F1461444816669158

Walton, K. (2019). World Leaders a-Twitter: Communication Platforms and AgendaBuilding During the 2018 NATO Summit.

Wang, Z., \& Ye, X. (2018). Social Media Analytics for Natural Disaster Management. International Journal of Geographical Information Science, 32(1), 49-72. https://doi.org/10.1080/13658816.2017.1367003

Zulfa, A., \& Firmansyah, N. A. (2019). Tingkat Pengetahuan Mitigasi Bencana (Hidrologis dan Geologi) dalam Lingkup Masyarakat di Kecamatan Gambiran Kabupaten

109 | Journal of Local Government Issues (Logos), 3 (2), September 2020, pp. 98-110 ISSN : 2620-8091 print | 2620-3812 online 
Banyuwangi. Prosiding Seminar Nasional Geotik, Universitas Muhammadiyah Surakarta, 264-268. https://publikasiilmiah.ums.ac.id/handle/11617/10821 